\title{
Characterization and Applications of Leaf Extracts of Hemigraphis Alternate
}

\author{
S. Agneeswari", M. Jansi
}

\begin{abstract}
Natural products carry out various capabilities and a lot of them have thrilling and useful organic activities. The gift take a look at turned into undertaken to analyze the bioactive compounds and the pharmacological capacity of leaf extract of Hemigraphis alternata. The presence of numerous compounds become characterized by way of FTIR and GCMS. ROS effect and wound recuperation assets have been analyzed and it discovered that crude extract is greater powerful inhibiting ROS manufacturing and it has high wound healing property with properly cellular migration in dose based way. The cytotoxic nature of leaf extract also analyzed with the aid of MTT assay and it suggests low IC50 value of $329.95 \mu \mathrm{G} / \mathrm{ml}$. The result discovered that the crude extract of H.Alternata leaf is a great wound healer with low cytotoxicity.
\end{abstract}

Keywords: Hemigraphis alternate, cytotoxicity, characterization, phytochemical.

\section{INTRODUCTION}

Herbal medicinal drug continues to be the mainstay of about 75 - eighty\% of the complete population, and the principal a part of conventional therapy involves the usage of plant extract and their energetic parts (Akerele 1993). Hemigraphis alternata is a tropical perennial herb chiefly grown as an decorative indoor and out of doors plant. The leaf has steel purple luster on higher surface and a strong darkish crimson on ventral aspect. In people remedy, the leaves are ground into a paste and applied on clean reduce wounds to promote wound recuperation and used to deal with anemia(Devi Priya 2013). It is a famous wound healing agent used in traditional medicine in India(Subramoniam 2001).The curative properties of medicinal flowers are because of the presence of secondary metabolites like alkaloids, glycosides, steroids, flavonoids, and vital oils that play an critical position in development of medication (Ongsakul 2009).

Previously it's miles stated that the phytoconstituents present in H.Colorata/ H.Alternata are phenols, saponins, flavonoids, terpenoids (Sheu 2012), coumarins, carbohydrates, carboxylic acid, xanthoproteins, tannins, proteins, alkaloids, steroids and sterol (Saravanan 2010). Natural antioxidants have a extensive range of biochemical sports which include inhibition of ROS technology, direct or indirect scavenging of

Revised Manuscript Received on December 15, 2019

S. Agneeswari1, Department of Zoology, Vivekananda College, Agasteeswaram, Kanyakumari, India.

M. Jansi, Department of Zoology, S.T. Hindu College, Nagercoil, India. E-mail: s.agneeswari@yahoo.com free radicals and alteration of intracellular redox capacity (Abdollahi 2005).Recent studies with different plant extracts revealed that phytochemical elements including flavonoids, terpenoids, and tannins can sell the wound-restoration manner (Souza 2007). Edwin (2011) stated that H.Change has capacity wound recovery property as it influences the fibroblast and endothelial cell formation, so herb derived elements are used for the for production of herb-included wound dressing materials (Asha Krishnan 2019). Herbal based H.Alternata Composite scaffold possess effective blood clotting and antibacterial pastime shows more advantageous mobile attachment and proliferation, The wound contraction and epithelialization were quicker in H. Colorata leaf paste applied mice (Annapoorna 2013).Therefore, the purpose of this observe changed into to assess the pharmacological ability like phytochemical materials, antioxidant, antibacterial, wound recuperation assets and cytotoxicity of the crude and solvent extracts of H.Alternata leaves. In this study we tried to characterize the bioactive compounds of Hemigraphis alternata extracts the use of FTIR and GCMS analysis and take a look at the effect of phytoconstituents like ROS activity, cytotoxicity and wound recuperation property at the cell migration and proliferation of fibroblast cells.

\section{II.MATERIALS AND METHODS}

\section{Sample collection}

The matured leaves of Hemigraphis alternata was collected from Kurunthancodeof Kanyakumari district. The plant was taxonomically identified by Professor Dr. P. Nagendra Prasad, Head, Department of Biotechnology, Sri Paramakalyani College, Alwarkurichi, Tirunelveli. Freshly collected $H$. alternata leaves were washed in running tap water for $3 \mathrm{~min}$. Then the plant parts were rinsed with sterile distilled water thoroughly to remove residues. Excess moisture was removed from the sterilized leaves.Then they were subjected to solvent and crude extraction.

\section{Preparation of crude and solvent Extracts}

About $10 \mathrm{~g}$ clean leaves of H.Alternatawas macerated in pestle and mortar at room temperature after which filtered using muslin material below strict aseptic situations and the

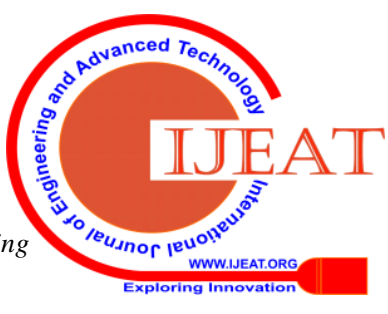


filtrate crude pattern became collected in sparkling sterilized glass tubes and saved at four ${ }^{\circ} \mathrm{C}$ till use (Goyal 2008).Fresh leaves have been cut into small pieces and to $5 \mathrm{~g}$ of leaves, 10 $\mathrm{ml}$ of solvent like Ethanol,Aqueous and Petroleum Ether were delivered one after the other and grounded with motor and pestle. The extracts had been boiled at $60^{\circ} \mathrm{C}$ for three hours, saved in a single day at $37^{\circ} \mathrm{C}$ after which filtered with Whatman No. 1 clear out paper. The extracts were dried and stored at $4{ }^{\circ} \mathrm{C}$

\section{FTIR Analysis}

Fourier remodel infrared (FTIR) spectroscopy is a way used to attain an infrared spectrum of absorption of strong, liquid or fuel sample. For measurements the samples were air dried and mixed with potassium bromide inside the ratio of one: a hundred. FTIR spectrum of samples was recorded on Shimazdu IR Prestige-21 FTIR instrument with a diffuse reflectance mode (DRS-8000) attachment. All measurements had been completed inside the variety of $400-4000 \mathrm{~cm}-1$ at a decision of four $\mathrm{cm}-1$ at room temperature the usage of a double beam. This variety changed into used to observe the essential vibrations and associated rotational vibrational shape (Anjana 2012).

\section{Gas Chromatography-Mass Spectrometry (GC-MS) analysis}

The GC-MS analysis of the pattern was performed the usage of Shimadzu GC-MS - QP2010 Gas Chromatography spectrometer with barely changed technique of (Senthil 2016).

\section{Cytotoxicity assay}

The Mouse Fibroblast Cell strains procured from NCCS, Pune were Cultured and Maintained until they reach $70 \%$ Confluence in T25 Flask at $37^{\circ} \mathrm{C}$ in a $5 \% \quad \mathrm{CO} 2$ Incubator.Afterwards, $200 \mu \mathrm{l}$ mobile suspension was seeded in a ninety six-nicely plate at the specified mobile density (20,000 cells in line with well), without the test agent and allowed the cells to grow for about 24 hours. Appropriate concentrations of Hemigraphis alternata leaf extract (25, 50, 100 , two hundred and $400 \mu \mathrm{g} / \mathrm{ml}$ ) dissolved in DMEM Media excessive glucose (Cat No. AL111, Himedia) have been added and incubated for twenty-four hours at $37^{\circ} \mathrm{C}$ in a five $\%$ $\mathrm{CO} 2$ surroundings. Camptothecin with the awareness of $25 \mu \mathrm{m}$ is used as a Positive Control for the Study. After the incubation duration, cast off the Spent Media and add one hundred $\mu$ l of MTT reagent(Cat No:4060, Himedia) changed into brought and incubated for three hours at $37^{\circ} \mathrm{C}$. After incubation duration, the formed formazan crystals have been dissolved with $100 \mu \mathrm{l}$ of DMSO (Cat No.1309, Sigma) and the absorbance readings had been taken via ELISA Reader (ELX 800, Biotek) at 570nm and the IC50 fee is calculated the usage of linear regression equation i.E. $\mathrm{Y}=\mathrm{Mx}+\mathrm{C}$ derived from the Cell viability graph. The viability of the cells became decided through the following method:
$\%$ of viability $=(\mathrm{OD}$ of Test compound treated Cells/OD of Untreated cells) x 100

\section{ROS study by flow cytometry}

To Detect the Protective nature of crude Extract of H.Alternata towards the Mouse fibroblast Cell traces, three $\mathrm{x}$ $10^{\wedge}$ five cells $/ 2 \mathrm{ml}$ have been seeded in 6 well ELISA Plate and incubated the cells for 24 hours at $37^{\circ} \mathrm{C}$ to attain excellent confluence. After 24hours, put off Spent Medium, wash the cells with $1 \mathrm{ml}$ of $1 \mathrm{X}$ DPBS and treat the cells with Met extract with the riskless attention of $100 \mu \mathrm{g} / \mathrm{ml}$ in first well of 6 well ELISA plate and labelled as Test and controls in $2 \mathrm{ml}$ of culture medium and incubate the cells for 12 hours. Remember to go away one of the wells as untreated for use as poor manipulate. Aspirate medium and wash with $1 \mathrm{ml}$ of $1 \mathrm{X}$ PBS. Immediately Treat the cells with the toxic compound $(\mathrm{H} 2 \mathrm{O} 2-200 \mu \mathrm{M})$ in $2 \mathrm{ml}$ of tradition medium besides the Cell Control and incubate the cells for four to five hours to induce pressure. Afterwards accumulate the cells through trypsinisation and centrifuge at 2000rpm/5minutes and suspend cells inside the H2DCFDA working answer at a density of one $\mathrm{x} 106$ cells $/ \mathrm{ml}$ and incubate at $37^{\circ} \mathrm{C}$ for half-hour blanketed from mild. Centrifuge the tubes at $150 \mathrm{x} \mathrm{g}$ for 5 mins. Remove the supernatant and lightly resuspend cells in $400 \mu \mathrm{l}$ of DPBS. Analyze with the aid of go with the flow cytometry using the $488 \mathrm{~nm}$ laser for excitation and detection at $535 \mathrm{~nm}$ (FL1).H2O2 used as a STD Control for the Study.

\section{Invitro scratch assay}

On the other hand, to assess the wound healing capacity Properties of the H.Alternata crude extract in opposition to the Normal Fibroblast Cells, 0.25 x 10^6 L929 cells had been seeded in 12 well ELISA plate and incubated at $37^{\circ} \mathrm{C}$ until they attain ninety\% Confluency. Afterwards, lightly and slowly scratch the monolayer with a new $200 \mu$ pipette tip throughout the middle of the properly and scratch ought to be usually in straight line with one route. Scratch any other directly line perpendicular to the first line to create a move in every properly. After scratching, gently wash the nicely twice with medium to put off the indifferent cells. Replenish the nicely with sparkling medium with $\mathrm{H}$. Alternata extract at the attention of $100 \mu \mathrm{g} / \mathrm{ml}$. Allantoin with $10 \mu \mathrm{g} / \mathrm{ml}$ used as a STDcontrol for the observe and seize the wound recuperation pix of cells by means of the usage of Inverted Biological Microscope (Biolinkz, China) at 5X Magnification in exclusive intervals at 0hour, 12hours, 24hours, 48hoursrespectively. The hole distance may be quantitatively evaluated using software program along with Image J Version 2.Zero.The test is finished in triplicates and the representatively one facts is shown. 


\section{RESULTS}

FTIR analysis of H.alternata leaf extract

Fourier transform infrared spectrophotometry were used to studyfunctional biomolecules present in the sample. The different solvent extracts such as aqueous, petroleum ether and ethanol were subjected to FTIR analysis. The spectrum showed that the aqueous and petroleum ether showed nearly the same high peak at $3296 \mathrm{~cm}^{-1}$, low peak at $2125 \mathrm{~cm}^{-1}$, and medium peak at $1635 \mathrm{~cm}^{-1}$ with alkynes, amides, carboxylic acids, amides and phenols with $\mathrm{C}-\mathrm{C}$ stretch, $\mathrm{NH}$ stretch, $\mathrm{NH}_{2}$ planes, C-O stretch and Aro-H-H bonds respectively. Where the spectrum of ethanol extract shows various peaks of bioactive compounds. The high sharp peak at $1087 \mathrm{~cm}^{-1}$ and $1045 \mathrm{~cm}^{-1}$ with alkylhalides, alcohols, amines, carboxylic acids, esters and ethers showing C- , C-F, C-N stretch and $\mathrm{CH}_{2}, \mathrm{CH}_{3}$ bonds. The medium peaks $3317 \mathrm{~cm}^{-1}$ and $2972 \mathrm{~cm}^{-1}$ contains phenols, carboxylic acid and alkanes with Aro-H-H bonds, C-O stretch and dimer $\mathrm{OH}$ bonds (Figure 1).

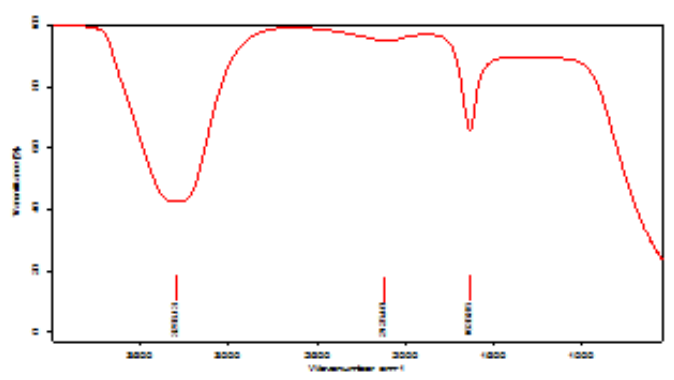

(a)

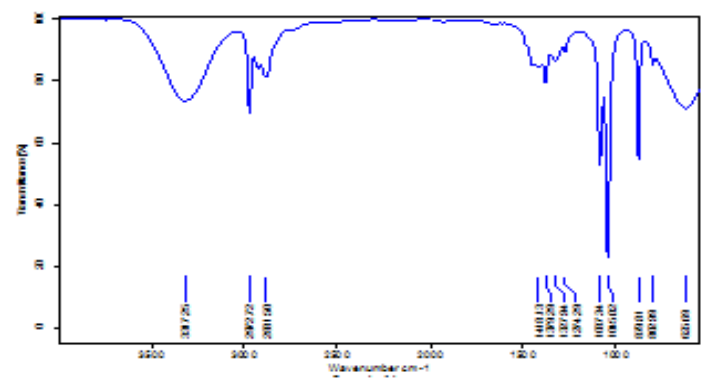

(b)

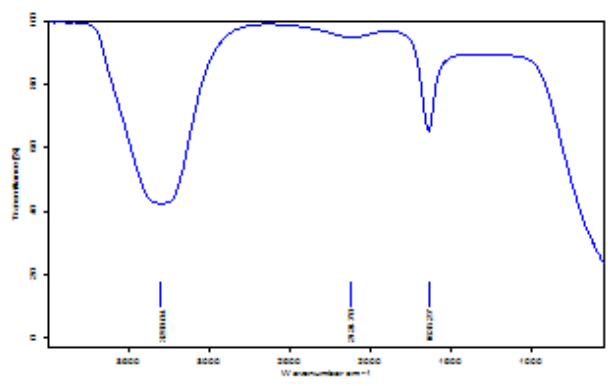

(c)

Figure 1: FTIR analysis of (a)aqueous leaf extract, (b) ethanol leaf extract and (c)Petroleum ether leaf extract of H.alternata

\section{GCMS analysis of $\boldsymbol{H}$. alternata leaf extract}

The GCMS analysis of $H$. alternata leaf extract revealed the presence of various novel compounds. The aqueous extract shows two peak indicating the presence of methyl salicylate and Diethyl phthalate. The ethanol extract shows 22 peak and the petroleum ether extract shows 23 peaks monitoring the presence of the different compounds (Figure 2, 3 and 4).

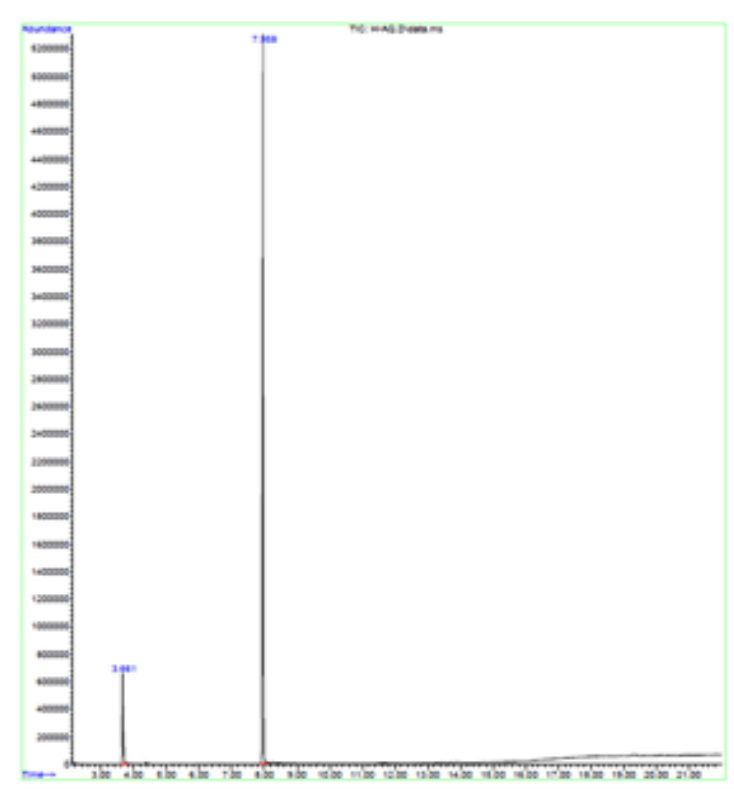

Figure 2: GCMS chromatogram of aqueous leaf extract of H.alternata

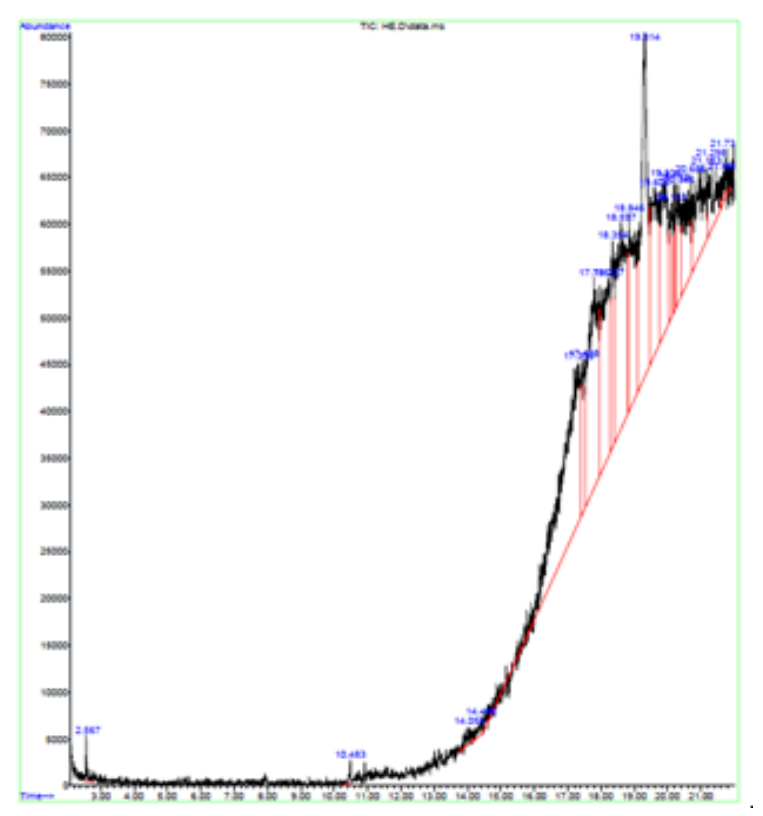

Figure 3: GCMS chromatogram of ethanol leaf extract of H.alternata

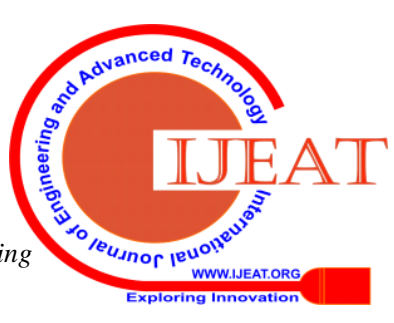




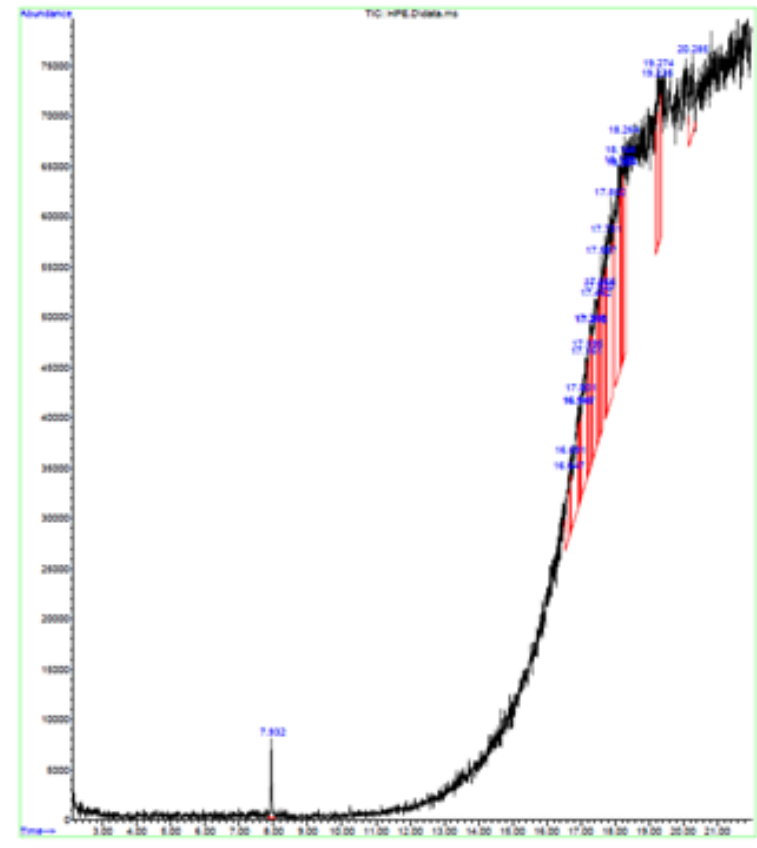

Figure 4: GCMS chromatogram of petroleum ether leaf extract of H.alternata

\section{MTT Assay Results}

The crude extract of H.alternata do not exhibited cytotoxic potential properties against the L929 cell lines by MTT Cytotoxicity Assay in the concentrations of the test compound ranging from $25-400 \mu \mathrm{g} / \mathrm{ml}$ respectively and the $\mathrm{IC}_{50}$ Value found at the concentration of $329.95 \mu \mathrm{g} / \mathrm{ml}$ at the incubation period of 24hours (Figure 5,6). The microscopical image of cytotoxicity analysis was mentioned in Figure 7.

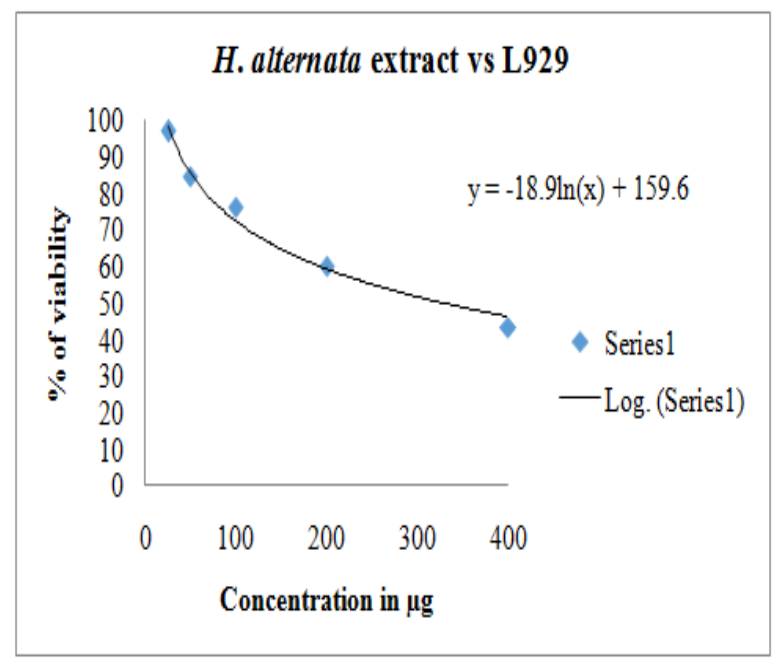

Figure 5: Scatter Graph showing the Cytotoxicity effect of H.alternata crude extract against the L929 Cell line after the incubation of 24 hours and the $\mathrm{IC}_{50}$ concentration observed at $329.95 \mu \mathrm{g} / \mathrm{ml}$.

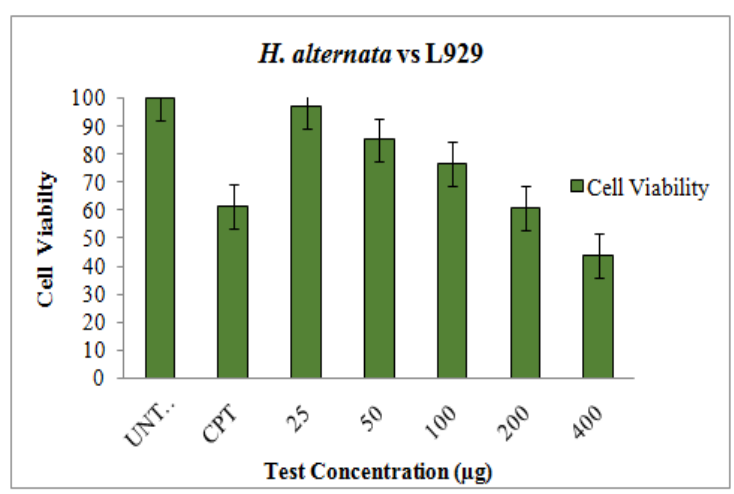

Figure 6: Bar graph showing the comparative cytotoxicity effect of $H$.alternata crude extract with $\mathrm{IC}_{\mathbf{5 0}}$ concentrations against the drug treated $\mathbf{L 9 2 9}$ cell lines after the incubation of 24 hours
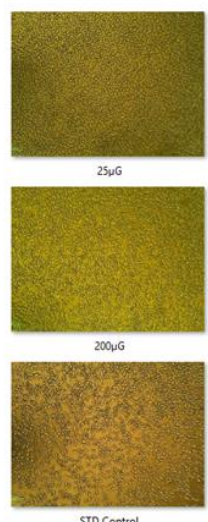

Figure 7: Microscopical image of $\mathrm{L929}$ cell showing cytotoxicity effect of $\boldsymbol{H}$.alternata crude extract.

\section{Reactive Oxygen species (ROS) study by flow cytometry}

The ROS expression Study by flow cytometry with the H2DCFDA staining suggesting that in L929 cells, the expression of H2DCFDA is very low in untreated L929 cells(11.52MFU) compared to the toxic control $\mathrm{H}_{2} \mathrm{O}_{2}$ showing $(200 \mu \mathrm{M})$ is $79.59 \mathrm{MFU}$. The ethanolic extract of H.alternata with the concentration of $100 \mu \mathrm{g} / \mathrm{ml}$ showing the 28.57 MFU of H2DCFDA expression by flow cytometry which is comparatively lesser than H2DCFDA expression of $\mathrm{H}_{2} \mathrm{O}_{2}$ and clearly confirming the ROS potential of the compound. Table 1, figure 8and 9 show the Mean Fluorescence Intensity of H2DCFDA stain against the untreated, toxic compound $\left(\mathrm{H}_{2} \mathrm{O}_{2}-200 \mu \mathrm{m}\right)$ and crude extract of H.alternata with nontoxic concentration of $100 \mu \mathrm{g} / \mathrm{ml}$ along with $\mathrm{H}_{2} \mathrm{O}_{2}$ treated L929 Cells.

Table 1: Table showing the Mean Fluorescence Intensity of H2DCFDA stain

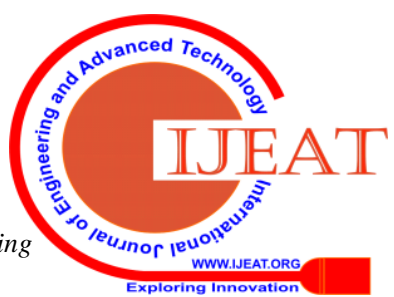




\begin{tabular}{|c|c|}
\hline MARKER & DCF-DA-Relative Mean Fluorescence Intensity \\
\hline Cell Control-L929 & 11.52 \\
\hline Toxic Compound- $\mathrm{H}_{2} \mathrm{O}_{2}(200 \mu \mathrm{m})$ & 79.59 \\
\hline H altenata-100 $\mu \mathrm{g}+\mathrm{H}_{2} \mathrm{O}_{2}(200 \mu \mathrm{m})$ & 28.57 \\
\hline
\end{tabular}

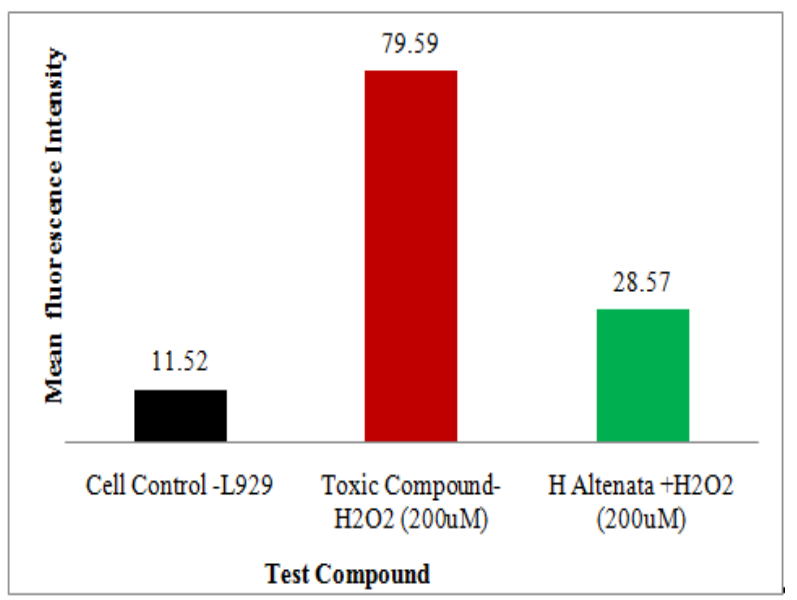

Figure 8: Overlay Bar Graph of Fluorescence Intensity of H2DCFDA stain against cells

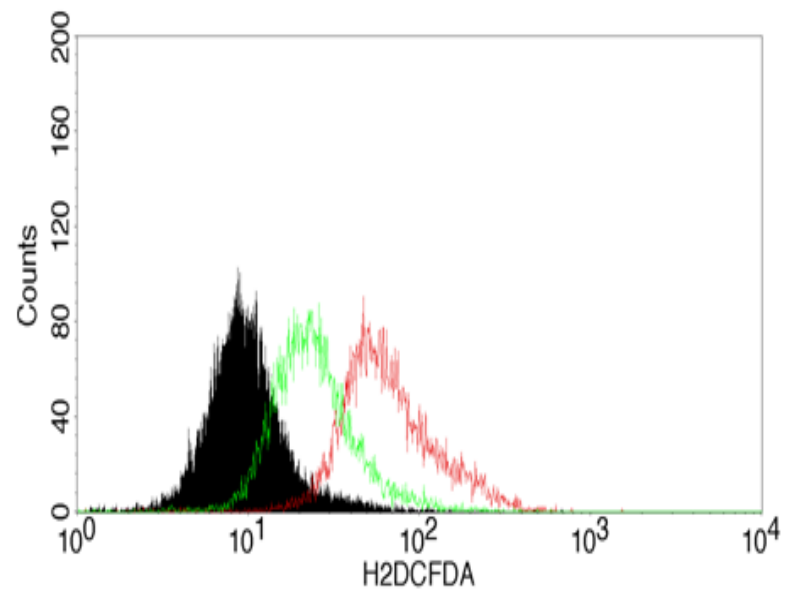

Fi

gure 9: Overlay Histogram of Fluorescence Intensity of H2DCFDA stain against cells Black line-Cell Control, Red line-Toxic Control, Green line- H Extract +toxic)

Wound healing potential study of $\mathrm{H}$. alternata against the L929 cell line.

In this Study, L929 (fibroblast) cells were used and by using image analyzer, the time required to closed the gap in the confluent cell monolayer with one concentration $(100 \mu \mathrm{g} / \mathrm{ml})$ is studied. The time taken to close the gap was plotted and compared with cell control is measured by using the Image $\mathbf{J}$ Analyzer Software. The H.alternata crude extract showed very significant wound healing potential properties compared to the STD Control, Allantoin used as positive control (Figure $10,11)$. Percentage of wound closure is determined in table 2.

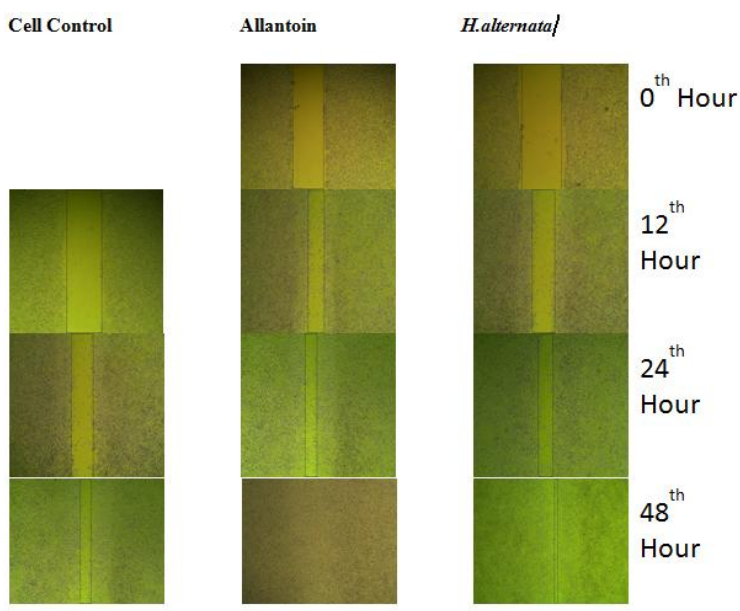

Figure 10: Wound healing potential study of H.alternata against the $\mathrm{L929}$ cell line.

Table 2: Percentage of wound closure

\begin{tabular}{|l|l|l|l|}
\hline \multicolumn{4}{|c|}{ Overlay of \% of Wound Closure Scored } \\
\hline Incubation & Untreated & Allantoin & H.alternata \\
\hline 0 hour & 0 & 0 & 0 \\
\hline 12 hour & 15.38461538 & 45.026178 & 40.48583 \\
\hline 24 hour & 41.98389054 & 63.79861 & 63.28351 \\
\hline 48 hour & 71.45748988 & 100 & 90.68826 \\
\hline
\end{tabular}

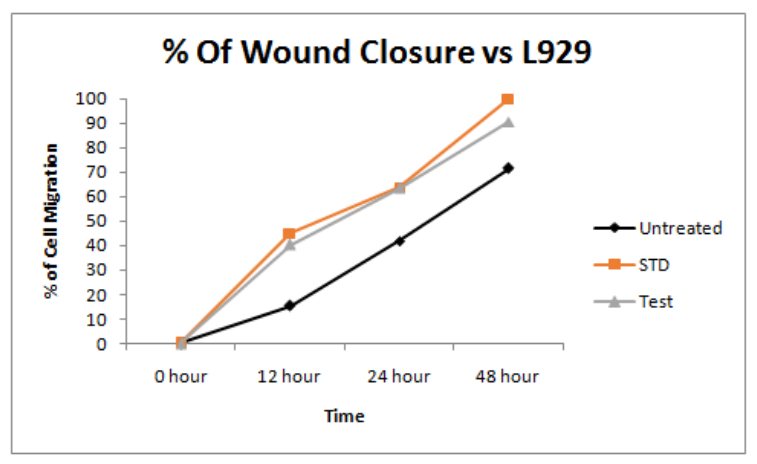

Figure 11: Scatter Graph Showing the Cell Monolayer Wound Closure using Scratch Assay in L929 Cell line

\section{DISCUSSION}

Plants are the richest useful resource of medication of traditional systems of medication, current medication, meals supplements, people medicines, pharmaceutical intermediates and chemical entities for synthetic tablets (Hammer 1999). The high sharp height at $1087 \mathrm{~cm}-1$ and $1045 \mathrm{~cm}-1$ with alkylhalides, alcohols, amines, carboxylic acids, esters and ethers displaying C- C,C-F, C-N stretch and $\mathrm{CH} 2, \mathrm{CH} 3$ bonds. Previous research guide our consequences that the plethora of hydroxyl businesses way that carbohydrates interact notably in hydrogen bonding and that there will be robust wide $\mathrm{O}-\mathrm{H}$ stretches(Smith 2017).

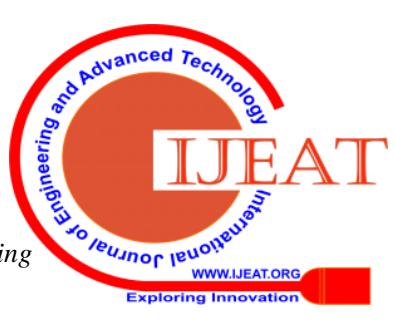


Bands at $2924 \mathrm{~cm}-1$ and at $2883 \mathrm{~cm}-1$ may be attributed to ethanol (Marcucci 2009). The band at $1645 \mathrm{~cm}-1$ will be associated with $\mathrm{C}=\mathrm{C}$ stretching vibration of fragrant earrings and to the vibration of $\mathrm{N}-\mathrm{H}$ of amines, $\mathrm{C}=\mathrm{O}$ of amides and carboxylic organizations based on propolis evaluation, this band will be associated with flavonoids and amino acids (Oliveira 2016). FTIR analysis that found out purposeful organization additives of amino acids, amides, amines, carboxylic acid, carbonyl compounds, organic hydrocarbons and halogens(Nithyadevi 2015).The methanol leaf extracts of Solanum torvumto affirm the presence of alcohol, alkanes, aromatic carboxylic acid, halogen compound, alkyl halide through the FTIR evaluation.The FTIR analysis discovered the presence of alkaloids because of $\mathrm{N}-\mathrm{H}$ stretching, polyphenols and flavonoids due to $\mathrm{O}-\mathrm{H}$ stretching, terpenes due to $\mathrm{C}-\mathrm{H}$ institution. The useful organizations are aldehydes, alkenes, amines, amides, alcohols, phenols, aromatics, carboxylic acids and anhydride, esters and lactones, ethers, quinines and organic halogen compounds. All those compounds belong to secondary plant metabolites(Paul 2011). The presence of most group of compounds in ethanol extract justify our outcomes of GCMS, anticancerous and wound restoration assets.

The GCMS analysis reveals the presence of chemical compounds with special biological activity. The Diethyl phthalate and Cyclododecanemethanol is a great antimicrobial agent, where Bis (Trimethylsilyl) diethyl silicate compound present in ethanol extract is also a antimicrobial compounds. The cytotoxic effect of the crude extract of the H.Alternata against the Mouse fibroblasts which include L929 with controls changed into investigated with the aid of the MTT assay in contrast with Camptothecin as a reference STD drug. It become discovered that cytotoxic hobby of the extract was now not observed till the $200 \mu \mathrm{g} / \mathrm{ml}$ awareness of the extract. However the MTT Cytotoxicity consequences of the H.Alternata crude extract against the L929 cell strains clearly confirming that the trustworthy nature of the extract till the $200 \mu \mathrm{g} / \mathrm{ml}$ attention of the compound while not having any facet outcomes at the wholesome fibroblast cellular increase.

H2DCFDA expression of the H. Alternata towards L929 cells the usage of BD FACSCalibur, Flow Cytometry. H2FCFDA histogram of the gated L929 singlets distinguishes cells on the M1 and M2 levels. (Here M2 refers to negative expression/vicinity and M1 refers to the nice expression/location). Gating of $\mathrm{M} 1$ and $\mathrm{M} 2$ phases is approximate and may be refined the usage of software program (Cell Quest Software, Version 6.Zero) analysis. In Cell Control, there may be no H2DCFDA expression since there's no pressure of $\mathrm{H} 2 \mathrm{O} 2$ treatment and having $6.20 \%$ of $\mathrm{H} 2 \mathrm{DCFDA}$ expression and in $\mathrm{H} 2 \mathrm{O} 2-200 \mu \mathrm{m}$ the stress is high with the H2DCFDA expression of $97.54 \%$ and within the H.Alternata alongside the publish treatment of $\mathrm{H} 2 \mathrm{O} 2$ treatment, the extract is suppressing the pressure of $\mathrm{H} 2 \mathrm{O} 2$ towards the cells with $50.88 \%$ of H2DCFDA expression. 10,000 events had been constantly analyzed for all of the assays. It is truly showed the protecting nature of H.Alternataextract against the fibroblast cells. ROS play important roles in mobile signaling and immune responses, however additionally they reason oxidative strain at better stages during wound recuperation. Wound recovery has been associated with a lower in pro-inflammatory cytokine degrees (Wang 2006). The experimental outcomes discovered that the crude extract of H.Alternata with the concentration of $100 \mu \mathrm{g} / \mathrm{ml}$ closed the gap in the Scratch of fibroblasts more efficaciously as compared to STD manage used inside the observe at the interval of 48hours and the gap/wound place is measured through using the Image J Analyzer Software

The H.Alternata crude leaf paste promotes excision wound healing (Bhargavi 2011, Pawar 2012). In mice, the leaf paste offers quicker wound contraction and epithelialisation but oral management is seen useless (Subramoniam 2001). The excision and incision wound model studies revealed that crude extract is comparable to conventional reference Vokadine (Saravanan 2010). Fibroblast cell cultures were proposed as a way for trying out wound recovery hobby invitro(Graham 1984).Adhesive intercellular junctions mediate touch between adjoining cells and provide positional cues to cells at some point of development, wound healing, and other tactics that require dynamic cell-mobile touch (Tepass 2000). The wound recuperation property known approximately Hemigraphis alternata may be due to this proliferation and migration of endothelial and fibroblast cells (Edwin 2011).

\section{CONCLUSION}

Medicinal plant life were generally utilized in traditional Indian medication for the treatment of diverse human ailments. The leaf extract of H.Alternata showed strong wound recovery interest with low cytotoxicity and properly ROS manipulate. It is concluded that H. Alternata carries bioactive compounds that can be used as a potential source of medication.

\section{REFERENCE}

1. Abdollahi, M., Larijani, B, Rahimi, R \& Salari, P (2005). "Role of oxidative stress in osteoporosis." Therapy2: 787-796.

2. Akerele, O. (1993). "Summary of World Health Organization Guidelines for the Assessment of Herbal Medicine." Herbal Gram22: 13-28.

3. Anjana, E. A., R (2012). "Efficacy of lectin-silver nanoparticle conjugate in the control of rice pathogen, Curvularia lunata (Wakker) Boedijn." INT J CURR SCI: 17-23.

4. Annapoorna, M., Kumar, PTS, Lakshman, LR, Lakshmanan, VK, Nair, SV \& Jayakumar, R (2013). "Biochemical properties of Hemigraphis alternata incorporated chitosan hydrogel scaffold." Carbohydrate Polymers92(2): 1561-1565.

5. Asha Krishnan, K. S. T. (2019). "Recent advances on herb-derived constituents-incorporated wound-dressing materials: A review." Polymers for Advanced Technologies30(4): 823-838. 
6. Bhargavi, C., Kumar, ADA, Kumar, NVSPP \& Babu, VR (2011). "Ancient and Modern View of Wound Healing: Therapeutic Treatments. ." RJPBCS2: 474-479.

7. Devi Priya, M. (2013). "Review on pharmacological activity of Hemigraphis colorata (Blume) H. G. Hallier." International Journal of Herbal Medicine1(3): 120-121.

8. Edwin, B. N., PD (2011). "In Vitro Evaluation of Wound Healing Property of Hemigraphis Alternata (Burm. F) T. Anders Using Fibroblast and Endothelial Cells." Biosciences, Biotechnology Research Asia8(1): 185-193.

9. Goyal, P., Khanna, A, Chauhan, A, Chauhan, G \& Kaushik, P (2008). "In vitro evaluation of crude extracts of Catharanthus roseus for potential antibacterial activity." International Journal of Green Pharmacy2(3): 176-181.

10. Graham, M., Diegelmann, RF \& Cohen, IK (1984). "An in vitro mode of fibroplasia: simultaneous quantification of fibroblast proliferation, migration, and collagen synthesis." Proc Soc Exp Biol Med176(3): 302-308.

11. Hammer, K., Carson, CF \& Riley, TV (1999). "Antimicrobial activity of essential oils and other plant extracts." J Appl Microbiol86(6): 985-990.

12. Marcucci, M. G., MEJ (2009). "Atividades Antimicrobiana e Antioxidante da Própolis do Estado do Ceará." Revista Fitos4(1) 81-86.

13. Nithyadevi, J. S., R (2015). "Phytochemical Screening and GC-MS, FT-IR Analysis of Methanolic Extract Leaves of Solanum torvum Sw. ." International Journal of Research Studies in Biosciences (IJRSB)3(9): 61-66.

14. Oliveira, R., Mancini, MC, Oliveira, FCS, Passos, TM, Quilty, B, Thiré, RMSM \& McGuinness, GB (2016). "FTIR analysis and quantification of phenols and flavonoids of five commercially available plants extracts used in wound healing." Matéria (Rio de Janeiro)21: 767-779.

15. Ongsakul, M., Jindarat, A \& Rojanaworarit, C (2009). "Antibacterial effect of crude alcoholic and aqueous extracts of six medicinal plants against Staphylococcus Aureus and Escherichia coli." J Health Res23: 153-156.

16. Paul, R., Irudayaraj, V, Johnson, M \& Patric, RD (2011). "Phytochemical and anti-bacterial activity of epidermal glands extract of Christella parasitica (L.) H. Lev." Asian Pac J Trop Biomed1(1): 8-11.

17. Pawar, R. T., FA (2012). "Plants that heal wounds- A review." Kerba Polonica58: 47-65.

18. Saravanan, J., Joshi, NH, Joshy, VG, Sutar, PS \& Karigar, AA (2010). "Wound healing activity of Hemigraphis colorata." Int J Contemp Res Rev1(5): 1-3.

19. Saravanan, J., Shariff, WR, Narasimhachar, HJ, Varatharajan, R, Joshi, VG \& Asif, AK (2010). "Preliminary photochemical studies of laves of Hemigraphis colorata." Res J Pharmacog Phytochem2: 15-17.

20. Senthil, J., Rameashkannan, MV \& Mani, P (2016). "Phytochemical Profiling of Ethanolic Leaves Extract of Ipomoea sepiaria (Koenig Ex. Roxb) " International Journal of Innovative Research in Science, Engineering and Technology5(3): 3140-3147.

21. Sheu, J., Jayakumar, T, Chang, C, Chen,Y, Priya ,S, Ong, E, Chiou, H \& Elizebeth, AR (2012). "Pharmacological actions of an ethanolic extracts of the leaves Hemigraphis colorata and Clerodendron phlomoides." Clin Mol Med4: 1-3.

22. Smith, B. (2017). "An IR spectral interpretation potpourri: Carbohydrates and alkynes." Spectroscopy (Santa Monica)32: 18-24.

23. Souza, S., Aquino, LC, Milach, AC Jr, Bandeira, MA, Nobre, ME \& Viana, GS (2007). "Antiinflammatory and antiulcer properties of tannins from Myracrodruon urundeuva Allemão (Anacardiaceae) in rodents." Phytother Res21(3): 220-225.

24. Subramoniam, A., Evans, DA, Rajasekharan, S \& Nair, GS (2001) "Effect of Hemigraphis colorata (Blume) H.G. Hallier leaf on wound healing and inflammation in Mice." Indian Journal of Pharmacology33(4): 283-285.

25. Tepass, U., Truong, K, Godt, D, Ikura, M \& Peifer, M (2000). "Cadherins in embryonic and neural morphogenesis." Nature Reviews Molecular Cell Biology1(2): 91-100.

26. Wang, X., Han, G, Owens, P, Siddiqui, Y \& Li, AG (2006). "Role of TGF beta-mediated inflammation in cutaneous wound healing." J Investig Dermatol Symp Proc11(1): 112-117. 